This is the author's final, peer-reviewed manuscript as accepted for publication. The publisher-formatted version may be available through the publisher's web site or your institution's library.

\title{
Structure and thermodynamics of a multimeric cavitand assembly
}

Christer B. Aakeröy, Prashant D. Chopade, Colette F. Quinn, and John Desper

\section{How to cite this manuscript}

If you make reference to this version of the manuscript, use the following information:

Aakeröy, C. B., Chopade, P. D., Quinn, C. F., \& Desper, J. (2014). Structure and thermodynamics of a multimeric cavitand assembly. Retrieved from http://krex.ksu.edu

\section{Published Version Information}

Citation: Aakeröy, C. B., Chopade, P. D., Quinn, C. F., \& Desper, J. (2014). Structure and thermodynamics of a multimeric cavitand assembly. CrystEngComm, 16(18), 37963801.

Copyright: @ The Royal Society of Chemistry 2014

Digital Object Identifier (DOI): doi:10.1039/c3ce42447b

Publisher's Link: http://dx.doi.org/10.1039/C3CE42447B

This item was retrieved from the K-State Research Exchange (K-REx), the institutional repository of Kansas State University. K-REx is available at http://krex.ksu.edu 


\title{
Structure and Thermodynamics of a Multimeric Cavitand Assembly
}

\author{
Christer B. Aakeröy, ${ }^{* a}$ Prashant D. Chopade, ${ }^{a}$ Colette F. Quinn, ${ }^{b}$ and John Desper ${ }^{a}$ \\ Received (in $X X X, X X X)$ Xth $X X X X X X X X X 20 X X$, Accepted Xth $X X X X X X X X X 20 X X$ \\ DOI: $10.1039 / b 000000 x$
}

\begin{abstract}
5 A set of $\mathrm{COOH} \cdots \mathrm{N}$ (pyridine) hydrogen bonds have been utilized in the targeted synthesis of a cavitandbased assembly. A cavitand appended with four pyridyl groups was synthesized from a Suzuki coupling of a tetrabromocavitand and 3-pyridyl boronic acid. The product resulting from the reaction between the tetra-pyridyl cavitand and 4-nitrobenzoic acid was investigated in solution using isothermal titration calorimetry (ITC) under equilibrium conditions, and in the solid state through single-crystal X-ray

10 diffraction and infrared spectroscopy. The results show that the targeted pentameric hydrogen-bonded architecture was isolated in the solid-state, and the infrared spectroscopy confirm the presence of $\mathrm{COOH} \cdots \mathrm{N}($ py) interactions. The same assembly, with a 1:4 cavitand:acid stoichiometry, is also present in solution in acetonitrile and the enthalpy of binding for this reaction is approximately $-45 \mathrm{~kJ} / \mathrm{mol}$.
\end{abstract}

\section{${ }_{15}$ Introduction}

In 1982, Cram defined 'cavitand' as a molecule with an inner cavity large enough to accommodate guest molecules or ions. ${ }^{1}$ These host structures have remained the focus of extensive attention for aesthetic reasons as well as for their ability to form 20 capsules with unique functions and properties. Molecular capsules based on dynamic covalent bonds, ${ }^{2}$ metal-coordination bonds, ${ }^{3}$ ionic interactions, ${ }^{4}$ non-covalent interactions, ${ }^{5}$ and solvophobic interactions ${ }^{6}$ are of considerable importance in catalysis, $^{7}$ molecular sensing, ${ }^{8}$ stabilization of reactive 25 intermediates, ${ }^{9}$ and recently as masking agents against undesired photochemical reactions. ${ }^{10}$ Although there are manysupramolecular interactions from which to choose when preparing capsules, the hydrogen bond remains the most widely used thanks to its tuneable strength, directionality and selectivity.

30

The assembly of large and complex multicomponent supramolecular structures with predictable connectivity and stoichiometry is a challenging goal in supramolecular chemistry. Furthermore, the actual characterization of the assemblies, 35 whether carried out in solution or in the solid state is frequently non-trivial. In particular, it is difficult to make reliable predictions about the precise nature of assembly and the relative stability of multimeric cavitand-based architectures in solution using solid-state X-ray diffraction data. In fact, the number of 40 papers that simultaneously report on matching solution- and solid-state data for resorcinarene-based supramolecular hosts and capsules is limited.

Many strategies for supramolecular synthesis of cavitand 45 assemblies begin with systematic studies of intermolecular interaction preferences of small molecules. Using such information, it is clear that the hydrogen-bond based complementarity of pyridine- and carboxylic acid moieties offers a path towards successful synthesis of a wide range of co${ }_{50}$ crystals. In fact, the $-\mathrm{COOH} \cdots \mathrm{N}$ (pyridine) hydrogen bond represents a versatile and robust heterosynthon which has been extensively utilized in supramolecular chemistry. ${ }^{11,12}$
Consequently, in order to prepare new multimeric cavitand assemblies, we employed a pyridyl functionalized cavitand as a 55 tetradentate hydrogen-bond acceptor and a carboxylic acid as the hydrogen-bond donor. As the host molecule of choice contains four hydrogen-bond acceptor sites and the hydrogen-bond donor is 4-nitrobenzoic acid, 3, the synthetic target is a pentameric assembly, Scheme 1. We were particularly interested in 60 establishing if data obtained from solid-state characterizations of the crystalline products could be directly related to solution-phase information. To this end, we report on the synthesis and assembly of a new cavitand-based assembly, and the subsequent characterization of this architecture using a combination of ${ }_{65}$ isothermal titration calorimetry (ITC) under equilibrium conditions in solution and X-ray crystallography. These experiments permit us to identify similarities and differences in solution versus solid-state structure.

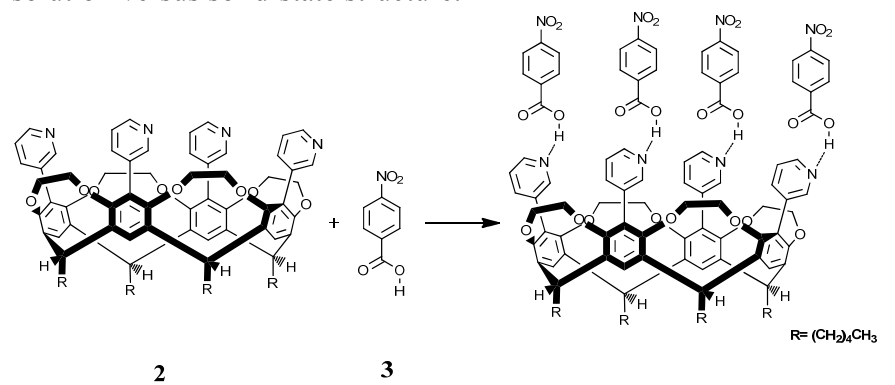

Scheme 1. Proposed assembly of a pentameric architecture.

\section{Experimental}

${ }^{1} \mathrm{H}$ NMR spectra were recorded on a Varian Unity plus $400 \mathrm{MHz}$ spectrometer in $\mathrm{CDCl}_{3}$. Data is expressed in parts per million $75(\mathrm{ppm})$ downfield shift from tetramethylsilane or residual protiosolvent as internal reference and are reported as position (in ppm), multiplicity ( $\mathrm{s}=$ singlet, $\mathrm{d}=$ doublet, $\mathrm{t}=$ triplet, $\mathrm{m}=$ multiplet), coupling constant $(\mathrm{J}$ in $\mathrm{Hz}$ ) and integration (number of protons). ${ }^{13} \mathrm{C}$ NMR spectra were recorded on a Varian Unity plus 80 $400 \mathrm{MHz}$ spectrometer in $\mathrm{CDCl}_{3}$ or $d$-DMSO with complete proton decoupling. Data is expressed in parts per million (ppm) shift relative to $\mathrm{CDCl}_{3}(77.00 \mathrm{ppm})$ and are reported as position 
(ס). Melting points were recorded on a Fisher-Johns melting point apparatus and are uncorrected. Infrared spectroscopy (IR) was done on a Nicolet 380 FT-IR. All chemicals were purchased from Aldrich and Fisher and used without further purification, unless 5 otherwise noted.

\section{Synthesis}

C-pentylcalix[4]resorcinarene, ${ }^{13} \quad$ C-pentyltetrabromocalix[4] resorcinarene, ${ }^{14}$ and the C-pentyltetrabromocavitand ${ }^{15} \mathbf{1}$ were synthesized according to literature procedures.

10

\section{C-pentyltetra(3-pyridyl) cavitand (2)}

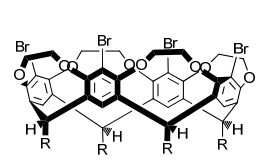

1

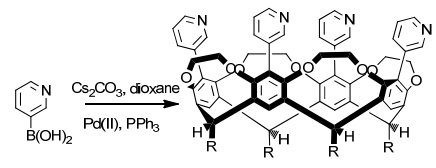

2
Scheme 2. Synthesis of the C-pentyltetra(3-pyridyl) cavitand.

To a $250 \mathrm{~mL}$ round-bottom flask, water $(4 \mathrm{~mL})$, pyridyl-315 boronic acid $(1.76 \mathrm{~g}, 14 \mathrm{mmol})$, and $\mathrm{PPh}_{3}(0.83 \mathrm{~g}, 32 \mathrm{mmol})$ in dioxane $(75 \mathrm{~mL})$ were added to a mixture of 1 (1.90 g, $16 \mathrm{mmol})$, $\left[\mathrm{PdCl}_{2}\left(\mathrm{PPh}_{3}\right)_{2}\right](278 \mathrm{mg}, 50 \mathrm{~mol} \%)$, and $\mathrm{Cs}_{2} \mathrm{CO}_{3}(7.81 \mathrm{~g}, 23$ $\mathrm{mmol})$ in dioxane $(90 \mathrm{~mL})$. After stirring for $5 \mathrm{~h}$ at $110^{\circ} \mathrm{C}$ in the dark, the reaction mixture was filtered on a celite pad and washed

20 three times with chloroform, and the solvent was evaporated to afford the crude product. The crude product was purified by column chromatography (500 g silica, hexane $\rightarrow$ hexane: ethyl acetate $\rightarrow 8: 2$ ethyl acetate : ethanol : $3 \%$ triethyl amine) to give $2\left(0.65\right.$ g, 35\%). M. p. $>280{ }^{\circ} \mathrm{C} .{ }^{1} \mathrm{H} \operatorname{NMR}\left(\delta_{\mathrm{H}} ; 400 \mathrm{MHz}\right.$, $\left.{ }_{25} \mathrm{CDCl}_{3}\right): 8.57(\mathrm{~d}, \mathrm{~J}=4.0 \mathrm{~Hz}, 4 \mathrm{H}), 8.37(\mathrm{~s}, 4 \mathrm{H}), 7.63(\mathrm{~s}, 4 \mathrm{H}), 7.56$ $(\mathrm{d}, \mathrm{J}=4 \mathrm{~Hz}, 4 \mathrm{H}), 7.34(\mathrm{~d}, \mathrm{~J}=4 \mathrm{~Hz}, 4 \mathrm{H}), 5.27(\mathrm{t}, \mathrm{J}=8 \mathrm{~Hz}, 4 \mathrm{H})$, 3.82-3.89 (m, 8H), 3.37-3.44 (m, 8H), 2.27-2.19 (m, 12H), 1.43$1.29(\mathrm{~m}, 24 \mathrm{H}), 0.91(\mathrm{t}, \mathrm{J}=8 \mathrm{~Hz}, 12 \mathrm{H}) ;{ }^{13} \mathrm{C} \mathrm{NMR}\left(\delta_{\mathrm{C}} ; 400 \mathrm{MHz}\right.$, $\left.\mathrm{CDCl}_{3}\right): 151.86,149.72,148.76,137.45,136.21,131.05,127.60$, $30124.72,123.09,72.17,34.66,33.91,31.84,27.55,22.63,14.08$. IR: 2924, 1567, 1480, 1269, 1089, 1061, 1042, 872, 809.

\section{Single crystals of 1 (2.5 acetonitrile)}

$1(0.19 \mathrm{~g}, 1.6 \mathrm{mmol})$ was dissolved in acetonitrile $(4 \mathrm{~mL})$. After 35 three days, prism-shaped orange crystals were obtained. M.p. $>280^{\circ} \mathrm{C}$

\section{Single crystals of 2(4.5 methanol)}

A vial containing 2 (40 mg, $0.036 \mathrm{mmol})$ dissolved in $2 \mathrm{~mL}$ 40 ethanol was kept in a sealed container filled with hexane at room temperature. After four days, prism-shaped colourless crystals were obtained. M.p. $>280^{\circ} \mathrm{C}$.

\section{Single crystals of $2 \cdot(3)_{4}$ hydrate (2.5 nitrobenzene)}

2 (10 mg, $0.009 \mathrm{mmol}), 3$ (6.0 $\mathrm{mg}, 0.04 \mathrm{mmol})$ and 2,6${ }_{45}$ dimethylnaphthalene $(1.4 \mathrm{mg}, 0.009 \mathrm{mmol})$ were placed in a vial containing nitrobenzene $(2 \mathrm{~mL})$ until a transparent homogeneous solution was obtained. After several days, prism-shaped yellow crystals were obtained. Dec. $230^{\circ} \mathrm{C}$; IR (neat) $v 2436$ and 1932 $\mathrm{cm}^{-1}(\mathrm{O}-\mathrm{H} \cdots \mathrm{N}, \mathrm{br}), 1730 \mathrm{~cm}^{-1}(\mathrm{C}=\mathrm{O})$. We were unable to grow
50 crystal suitable for single-crystal X-ray diffraction from other solvents including chloroform.

\section{ITC Experiments}

Dry chloroform (Fisher scientific) was used as a solvent for the ${ }_{55}$ ITC experiments to minimize any inconsistency resulting from the presence of water. Dry and analytically pure samples of $\mathbf{2}$ and 3 were used for titrations. All ITC measurements were performed using a commercial calorimeter Nano ITC-Waters LLC at $298 \mathrm{~K}$ with a cell volume of $1.00 \mathrm{~mL}$. on a Nano ITC instrument. In a 60 typical experiment, the sample cell of the calorimeter was rinsed five times with methanol, and then rinsed five times with chloroform. A similar procedure was repeated on the reference cell. The reference cell was filled with chloroform and the sample cell was filled with $0.188 \mathrm{mM}$ 4-nitrobenzoic acid 3. A $12 \mathrm{mM}$ 65 solution of C-pentyltetra(3-pyridyl) cavitand 2 in chloroform and equilibrated at $25{ }^{\circ} \mathrm{C}$ for 1 hour. After thermal equilibrium was attained, $8 \mu \mathrm{L}$ aliquots of C-pentyltetra(3-pyridyl) cavitand 2 $(12 \mathrm{mM})$ were injected into the sample cell; 30 such injections were made with a time delay of $400 \mathrm{~s}$ between each addition. The 70 enthalpy change after each addition was measured. The titration was repeated twice.

The standard NanoAnalyze software was employed for integration of heat changes for each step in the titration. The 75 signals from the experiment are plotted in $\mu \mathrm{J} / \mathrm{sec}$ as a function of time, interpreting the power needed to maintain the reference and sample cell at the same temperature. The number of pulses corresponds to the heat released/absorbed with injection of the ligand. These can be integrated to obtain the total heat change per 80 injection. As a concentrated solution of the C-pentyltetra(3pyridyl)cavitand $\mathbf{2}$ is injected into a dilute solution of 4nitrobenzoic acid, the hydrogen-bond interactions between host and guest result in exothermic binding events, Fig. 1. Upon repeated addition of 2 , fewer and fewer acid molecules remain for 85 binding and the heat liberated decreases. Ultimately, no more acid molecules are available for binding and no further heat release is observed. In the sample cell, $2.35 \times 10^{-4} \mathrm{mmol}$ of 4nitrobenzoic acid 3 were present and a 1:4 stoichiometry (as expected based upon the crystal structure), should require $1 / 4^{\text {th }}$ 90 times the amount of 3-pyridylcavitand (i.e. $5.875 \times 10^{-5} \mathrm{mmol}$ ). In each injection of $2,9.6 \times 10^{-5} \mathrm{mmol}$ of cavitand is present. In less than three injections, all the acid molecules in the sample cell should bind to the cavitand molecule. However, it took a total of nine injections of $\mathbf{2}$ before the exothermic events stopped. The 95 observation made here that the expected supramolecular stoichiometry does not translate directly into corresponding molar ratios during the resulting titration is not unprecedented. For example, Turnbull and Daranas showed in a study of $\mathrm{Ba}^{2+}$ and 18-crown- 6 that even though the titration produced exothermic 100 events well past the expected stoichiometry, the values obtained for $K_{\mathrm{a}}$ and $\Delta H^{\circ}$ are reasonable as the value of $\mathrm{N}$ is fixed. ${ }^{16}$ As long as a substantive part of the isotherm displays a sufficiently large signal-to-noise ratio, and that stoichiometry and host/guest concentrations are known, ITC measurements can provide 105 reliable data. ${ }^{17}$

The heat resulting from each individual injection is integrated 
with respect to time and plotted against the molar ratio of the two components. These values are fitted using the independent model from the software NanoAnalyze resulting in information about enthalpy change $(\Delta H)$, association constant $\left(K_{\mathrm{a}}\right)$, and 5 stoichiometry $(\mathrm{N})$, Fig. 1 . Since $\mathrm{N}$ was estimated to be 0.25 , the numerical value of $\mathrm{N}$ was allowed to vary in the range of 0.2 to 0.3. $\Delta H$ and $K_{\mathrm{a}}$ were allowed to vary freely.

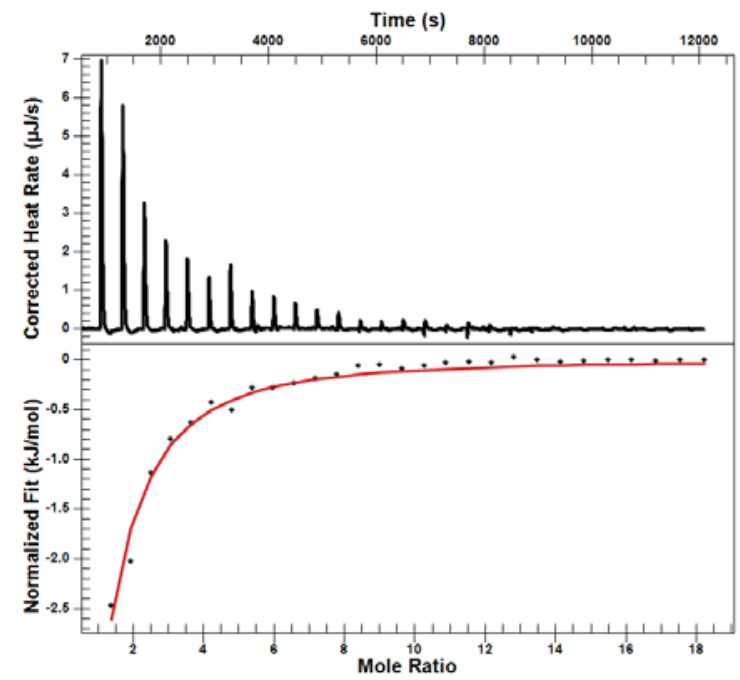

Figure 1. ITC titration curve of C-pentyltetra(3-pyridyl)cavitand vs. 4-nitrobenzoic acid.

Table 1. Comparison of thermodynamic parameters for the complexation of $\mathbf{2}$ with 4-nitrobenzoic acid.

\begin{tabular}{cccccc}
\hline & $K$ & $\Delta G(\mathrm{~kJ} / \mathrm{mol})$ & $\Delta H(\mathrm{~kJ} / \mathrm{mol})$ & $\mathrm{N}$ & $\Delta S(\mathrm{~J} / \mathrm{mol} \mathrm{K})$ \\
Experiment 1 & 4880 & -21.0 & -36.1 & 0.30 & -50.0 \\
Experiment 2 & 3380 & -20.1 & -35.5 & 0.25 & -51.0 \\
Mean & 4130 & -20.6 & -35.8 & 0.3 & -50.5 \\
Standard & 750 & 0.5 & 0.3 & 0.03 & 0.5 \\
$\quad$ Error & & & & &
\end{tabular}

${ }^{a}$ For note on errors see reference. ${ }^{18}$ 15

\section{Crystal structure determination}

X-ray data were collected on a SMART APEX II system with Mo radiation for $\mathbf{1}$ and $\mathbf{2}$ or a Bruker Kappa APEX II system with $\mathrm{Cu}$ radiation for $3 .{ }^{19} \mathrm{An}$ Oxford Cryostream 700 low-temperature 20 device set to $120^{\circ} \mathrm{K}$ was used to control temperature. Initial cell constants were found by small widely separated "matrix" runs. Data collection strategies were determined using COSMO. ${ }^{20}$ Scan speeds and scan widths were chosen based on scattering power and peak rocking curves. Unit cell constants and orientation

25 matrices were improved by least-squares refinement of reflections thresholded from the entire dataset. Integrations were performed with SAINT, ${ }^{21}$ using these improved unit cells as a starting point. Precise unit cell constants were calculated in SAINT from the final merged datasets. Lorenz and polarization 30 corrections were applied. Absorption corrections were applied using SADABS. ${ }^{22}$ Datasets were reduced with SHELXTL. ${ }^{23}$ The structures were solved by direct methods without incident. Unless otherwise noted, hydrogen atoms were assigned to idealized positions and were allowed to ride. Isotropic thermal parameters 35 for the hydrogen atoms were constrained to be $1.5 x$ (methyl) / $1.2 \mathrm{x}$ (all other) that of the connected atom.
1; The "EADP" command was applied to pairwise constrain the thermal parameters of the disordered side chains. The "SIMU" command was applied to restrain the thermal parameters of the 40 last two atoms on each disordered side chain (labelled "C25A/B" "C26A/B"). The "DFIX" command restrained the bond lengths and angles of the alkyl side chains. Ethanol solvent molecules were restrained to similar geometries using the "SAME" command, and the thermal parameters for each molecule were 45 constrained with the "EADP" command. Occupancies for the disordered solvent molecules were allowed to vary until late in refinement, at which point their occupancies were fixed.

2•(3) ${ }_{4}$; Coordinates of the carboxylic acid hydrogen atoms "H41" were allowed to refine. Two of the solvent molecules were 50 disordered, and closely located atoms in different parts were pairwise constrained with "EADP" commands. Similarly, thermal parameters for disordered side chains were pairwise constrained with the "EADP" command. The "DFIX" command restrained the bond lengths and angles of the alkyl side chains. For 55 crystallographic parameters see Table 2 and Table S1 (ESI).

Table 2. Crystal data for 2 and $\mathbf{2 \bullet ( 3 )} 4$.

\begin{tabular}{|c|c|c|}
\hline Parameter & 2 & $2 \cdot(3)_{4}$ \\
\hline Empirical formula & $\mathrm{C}_{170} \mathrm{H}_{222} \mathrm{~N}_{8} \mathrm{O}_{25}$ & $\mathrm{C}_{238} \mathrm{H}_{237} \mathrm{~N}_{21} \mathrm{O}_{60}$ \\
\hline Molecular weight & 2777.56 & 4351.49 \\
\hline Color, Habit & colourless prism & yellow prism \\
\hline Crystal system & Triclinic & Monoclinic \\
\hline Space group, $\mathrm{Z}$ & $\mathrm{P}-1,1$ & $\mathrm{P} 2(1) / \mathrm{n}, 2$ \\
\hline \multirow[t]{2}{*}{ a, $\AA$} & $12.7536(6)$ & $13.3210(9)$ \\
\hline & $13.7525(7)$ & $52.697(4)$ \\
\hline \multicolumn{3}{|l|}{$\mathrm{b}, \AA$} \\
\hline & $24.5901(12)$ & $16.3401(11)$ \\
\hline \multicolumn{3}{|l|}{$\mathrm{c}, \AA$} \\
\hline & $105.279(2)$ & 90.00 \\
\hline \multicolumn{3}{|l|}{$\alpha,^{\circ}$} \\
\hline & $95.784(2)$ & $109.773(3)$ \\
\hline \multicolumn{3}{|l|}{$\beta,^{\circ}$} \\
\hline & $102.120(2)$ & 90.00 \\
\hline \multicolumn{3}{|l|}{$\gamma,{ }^{\circ}$} \\
\hline Volume, $\AA^{3}$ & $4011.7(3)$ & 10794.1(13) \\
\hline X-ray wavelength & 0.71073 & 1.54178 \\
\hline$\mu, \mathrm{mm}^{-1}$ & 0.076 & 0.805 \\
\hline $\begin{array}{l}\text { Crystal size, } \\
\mathrm{mm} \times \mathrm{mm} \times \mathrm{mm}\end{array}$ & $0.30 \times 0.25 \times 0.20$ & $0.30 \times 0.22 \times 0.14$ \\
\hline \multirow{2}{*}{\multicolumn{3}{|c|}{ Reflections }} \\
\hline & & \\
\hline collected & 59661 & 71066 \\
\hline independent & 25761 & 19052 \\
\hline observed & 15075 & 15436 \\
\hline Threshold expression & $>2 \quad$ (I) & $>2 \quad$ (I) \\
\hline $\mathrm{R}_{1}$ (observed) & 0.0963 & 0.0629 \\
\hline$w \mathrm{R}_{2}$ (all) & 0.3349 & 0.1806 \\
\hline$S$ & 1.046 & 1.092 \\
\hline$\Delta \rho \max / \min$ & $1.428 /-0.934$ & $0.725 /-0.665$ \\
\hline$\Theta_{\text {full }}^{\circ}{ }^{\circ}$ & 31.54 & 67.50 \\
\hline Completeness to $\Theta_{\text {full }}$ & 0.964 & 0.964 \\
\hline
\end{tabular}

\section{${ }_{60}$ Results and Discussion}

The crystal structure of $\mathbf{1}$ shows that one acetonitrile molecule resides between the pentyl feet of the cavitand and one acetronitrile molecule encapsulated in the body and upper rim of cavitand, Figure 2. The latter guest/solvent molecule shows no 65 orientational preference, but the orientation of the acetonitrile molecule encapsulated between the feet of the cavitand (the nitrile moiety is pointing towards the body of the cavitand) is consistent with data from eight out of eight structures obtained from a combination of reported ${ }^{24}$ and in-house crystallographic 70 data of acetonitrile solvated cavitands. This preferred orientation 
of acetonitrile guest may be attributed to $\mathrm{CH}_{3} \mathrm{CN} \cdots \mathrm{H}-\mathrm{C}$ (solvent $\cdots$ cavitand) interaction.

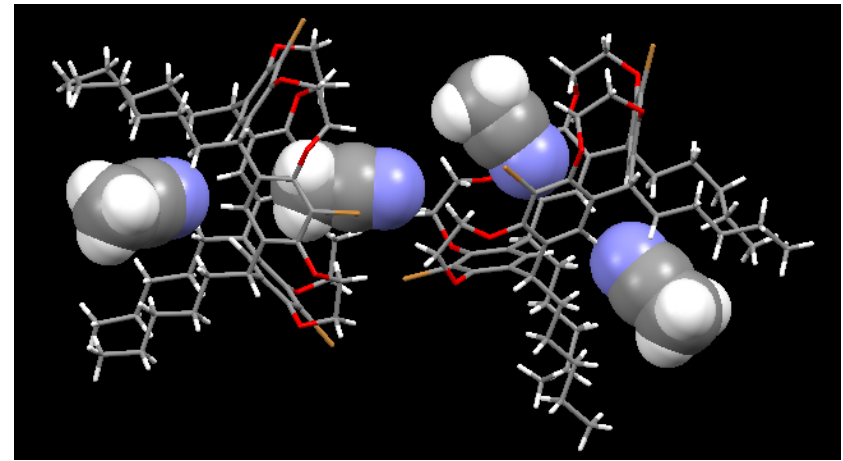

Figure 2. Crystal structure of $\mathbf{1}$ with acetonitrile guest molecules shown in space filling mode.

The pyridyl functionalized cavitand 2 was synthesized using a Suzuki coupling reaction of the tetrabromocavitand with 3pyridyl boronic acid in moderate yield. The structure 10 determination of 2 shows that the shape and size of the cavity remains unchanged with four pyridyl groups appended on the upper rim of the cavitand scaffold, Figure 3.

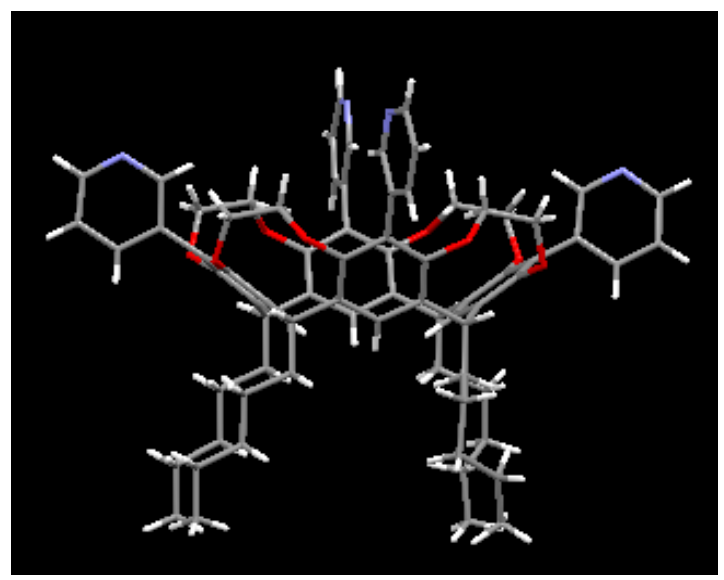

(a)

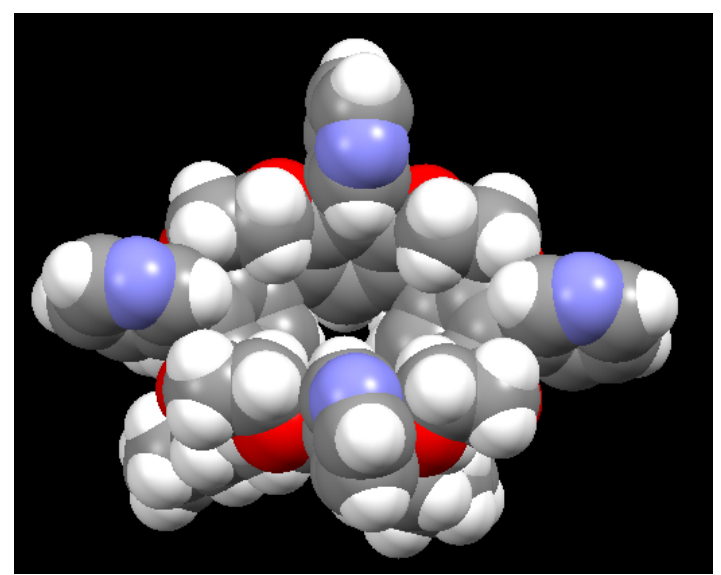

(b)
Figure 3. Crystal structure of $\mathbf{2}$ showing (a) capped stick model and (b) top view with space filling model (disordered ethanol and other solvent molecules were removed for clarity).

Next, we examined the host-guest properties of $\mathbf{2}$ in solution. The association constant $\left(K_{\mathrm{a}}\right)$ of 2 and 4-nitrobenzoic acid was determined in chloroform at $298 \mathrm{~K}$ via isothermal titration 25 calorimetry (ITC). The determination of the thermodynamic data from the ITC experiment requires the knowledge of the binding stoichiometry of the formed complexes. The estimated stoichiometry of $\mathbf{2}$ with 4-nitrobenzoic acid should be close to 0.25 , due to four binding sites of C-pentyltetra(3-pyridyl)cavitand 30 available to bind four 4-nitrobenzoic acids. We obtained value of $\mathrm{N}=0.28$ based on the ITC titrations. The association constant for the formation of the pentamer is approximately $4.1 \times 10^{3}$, and the assembly is enthalpically driven, with a $\Delta H$ value of approximately $-35 \mathrm{~kJ} / \mathrm{mol}$. This value corresponds to a 35 stabilization of approximately $9 \mathrm{~kJ}$ for each $\mathrm{COOH} \cdots \mathrm{N}($ py) hydrogen-bond which is very reasonable given the the presence of a highly polar solvent such as acetonitrile. The assembly process is essentially entropy neutral.

${ }_{40}$ To analyze this assembly in solid-state single crystals of $\mathbf{2} \cdot\left(3 \mathbf{3}_{\mathbf{4}}\right.$ in nitrobenzene as a solvent were grown. We analyzed the crystals by IR spectroscopy and found broad stretches at 1900 and 2500 $\mathrm{cm}^{-1}$ (see ESI), characteristic of $\mathrm{COOH} \cdots \mathrm{N}($ py) hydrogen bonds.

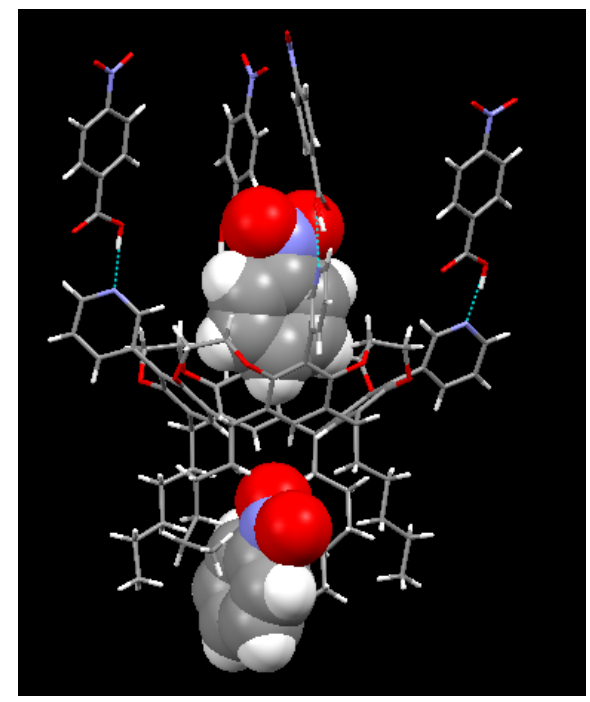

Figure 4. Crystal structure of $\mathbf{2} \cdot(3)_{4}$ showing pentameric assembly with two nitrobenzene molecules in space filling..

The structure determination of $\mathbf{2} \cdot(3)_{4}$ shows a pentameric co${ }_{50}$ crystal with one molecule of $\mathbf{2}$ binding to four molecules of 4nitrobenzoic acid via near-linear hydrogen bonds. Moreover, two nitrobenzene molecules are encapsulated within the host, Figure 4. The nitro moiety of the solvent positioned between the legs of the cavitand is oriented towards the center of the host, similarly to ${ }_{55}$ the behaviour of the nitrile moiety in encapsulated acetonitrile guests. The orientation of nitrobenzene is likely governed by $\mathrm{NO}_{2} \cdots \mathrm{H}-\mathrm{C}$ (guest $\cdots$ host) hydrogen bonding. The ability of molecular hosts to impart specific orientation of guests within the 
interior cavity is of great interest for designing molecular capsules that can act as region-selective reaction chambers. ${ }^{25}$

In summary, the combination of X-ray crystallography and ITC 5 for characterizing supramolecular reactions and products provides a more complete picture of the host-guest chemistry and demonstrates that the targeted pentameric supramolecular assembly, comprising a tetrapyridyl cavitand host and four 4nitrobenzoic acid molecules, could be obtained in solution as well 10 as in the solid state. This study illustrates the importance of utilizing complementary solution- and solid-state techniques in order to fully capture the structural chemistry as well as thermodynamic aspects of synthetic supramolecular chemistry.

\section{Acknowledgment}

${ }_{15}$ We are grateful for financial support from NSF (CHE-0957607).

\section{Notes and references}

${ }^{a}$ Department of Chemistry, Kansas State University, Manhattan, KS, 66506, USA. E-mail: aakeroy@ksu.edu

$20{ }^{b}$ TA Instruments, Inc, Lindon, UT

$\dagger$ Electronic supplementary information (ESI) available: Details of the crystallographic work and cif files. CCDC reference numbers 973362 , 973363 and 973364 . For crystallographic data in CIF or other electronic format see DOI: 10.1039/b000000x/

\section{References}

${ }^{1}$ (a) J. R. Moran, S. Karbach, D. J. Cram, J. Am. Chem. Soc. 1982, 104 5826; (b) D. J. Cram, Science 1983, 219, 1177; (c) D. Cram, H. Kim, C. Knobler, E. Maverick, J. Ericson, R. Helgeson, J. Am. Chem. Soc. 1988, 110, 2229.

${ }^{2}$ N. Nishimura, K. Kobayashi, J. Org. Chem. 2010, 75, 6079.

${ }^{3}$ (a) O. D. Fox, M. G. B. Drew, P. D. Beer, Angew. Chem., Int. Ed. 2000, 39, 135; (b) L. Pirondini, F. Bertolini, B. Cantadori, F. Ugozzoli, C. Massera, F. Dalcanale, Proc. Natl. Acad. Sci. USA 2002, 99, 4911; (c) M. Yoshizawa, Y. Takeyama, T. Okano, M. Fujita, J. Am. Chem. Soc. 2003, 125, 3243; (d) M. Yoshizawa, S. Miyagi, M. Kawano, K. Ishiguro, M. Fujita, J. Am. Chem. Soc. 2004, 126, 9172.

${ }^{4}$ (a) F. Corbellini, R. Fiammengo, P. Timmerman, M. Crego-Calama, K. Versluis, A. J. R. Heck, I. Luyten, D. N. Reinhoudt, J. Am.Chem. Soc. 2002, 124, 6569; (b) G. V. Oshovsky, D. N. Reinhoudt, W. Verboom, J. Am. Chem. Soc. 2006, 128, 5270.

5 (a) R. G. Chapman, J. C. Sherman, J. Am. Chem. Soc. 1995, 117, 9081; (b) L. R. MacGillivray, J. L. Atwood, Nature 1997, 389, 469; (c) T. Heinz, D. M. Rudkevich, J. Rebek, Nature 1998, 394, 764; (d) A. Shivanyuk, E. F. Paulus, V. Böhmer, Angew. Chem., Int. Ed. 1999, 38, 2906; (e) K. Kobayashi, T. Shirasaka, K. Yamaguchi, S Sakamoto, E. Horn, N. Furukawa, Chem. Commun. 2000, 41. (f) M. H. K. Ebbing, M.-J. Villa, J.-M. Valpuesta, P. Prados, J. de Mendoza, Proc. Natl. Acad. Sci. U.S.A. 2002, 99, 4962; (g) K. Kobayashi, K. Ishii, S. Sakamoto, T. Shirasaka, K. Yamaguchi, J. Am. Chem. Soc. 2003, 125, 10615; (h) F. Sansone, L. Baldini, A. Casnati, E. Chierici, G. Faimani, F. Ugozzoli, R. Ungaro, J. Am. Chem. Soc. 2004, 126, 6204; (i) D. Ajami, J. Rebek, J. Am. Chem. Soc. 2006, 128, 5314; (j) M. Yamanaka, K. Ishii, Y. Yamada, K. Kobayashi, J. Org. Chem. 2006, 71, 8800; (k) H. Kitagawa, Y. Kobori, M. Yamanaka, K. Yoza, K. Kobayashi, Proc. Natl. Acad. Sci. U.S.A. 2009, 106, 10444; (1) C. B. Aakeröy, A. Rajbanshi; J. Desper,Chem. Commun., 2011, 47, 11411; (m) C. B. Aakeröy, A. Rajbanshi, P. Metrangolo, G. Resnati, M. F. Parisi, J. Desper, T. Pilati, T. CrystEngComm, 2012, 14, 6366.
${ }^{6}$ M. D. Giles, S. Liu, R. L. Emanuel, B. C. Gibb, S. M. Grayson, J. Am. Chem. Soc. 2008, 130, 14430.

${ }^{7}$ R. Hooley, J. Rebek, Org. Biomol. Chem. 2007, 5, 3631.

8 (a) S. Zampolli, P. Betti, I. Elmi, E. Dalcanale, Chem. Commun. 2007,2790; (b) L. Pirondini, E. Dalcanale, Chem. Soc. Rev., 2007, 36, 695; (c) R. Pinalli, M. Suman, E. Dalcanale, Eur. J. Org. Chem. 2004, 451.

${ }^{9}$ T. Iwasawa, R. Hooley, J. Rebek Science 2007, 317, 493.

${ }^{10}$ N. Nishimura, K. Kobayashi, J. Org. Chem. 2010, 75, 6079.

${ }^{11}$ (a) J. J. Kane, R.-F. Liao, J. W.Lauher, F. W. Fowler, J. Am. Chem. Soc. 1995, 117, 12003; (b) C.V.K. Sharma, M. J. Zaworotko, Chem.Commun. 1996, 2655; (c) M. Grunert, R. A. Howie, A. Kaeding, C. T. Imrie, J. Mater. Chem. 1997, 7, 211; (d) V. R. Pedireddi, S. Chatterjee, A. Ranganathan, Tetrahedron 1998, 54, 9457, (e) M. Amai, T. Endo, H. Nagase, H. Ueda, M. Nakagaki, Acta Crystallogr. 1998, C54, 1367; (f) G.T.R. Palmore, T.-J.M. Luo, M. T. McBride-Wieser, E. A. Picciotto, C. M. Reynoso-Paz, Chem. Mater. 1999, 11, 3315; (g) C. B. Aakeröy, A. M. Beatty, M. Tremayne, D. Rowe, Cryst. Growth Des. 2001, 1, 377; (h) P. Vishweshwar, A. Nangia, V. M. Lynch, J. Org. Chem. 2002, 67, 556.

12 (a) K. Kobayashi, T. Shirasaka, K. Yamaguchi, S. Sakamoto, E. Hornac, N. Furukawa, Chem. Commun. 2000, 41; (b) K. Kobayashi, K. Ishii, S. Sakamoto, T. Shirasaka, K. Yamaguchi, J. Am. Chem. Soc. 2003, 125, 10615; (c) M. Yamanaka, K. Ishii, Y. Yamada, K Kobayashi, J. Org. Chem. 2006, 71, 8800.

${ }^{13}$ Y. Aoyama, Y. Tanaka, S. Sugahara, J. Am. Chem. Soc. 1989, 111, 2167.

${ }^{14}$ J. A. Bryant, M. T. Blanda, M. Vincenti, D. J. Cram, J. Am. Chem. Soc. 1991, 113, 2167

${ }^{15}$ R. C. Helgeson, K. Paek, C. B. Knobler, E. F. Maverick, D. J. Cram, J. Am. Chem. Soc. 1996, 118, 5590.

${ }^{16}$ W. B. Turnbull; A. H. Daranas, J. Am. Chem. Soc., 2003, 125, 14859.

${ }^{17}$ M. I. Ashiq, B. F. Tesfatsion, F. Gaggini, S. Dixon, J. D. Kilburn, Chem. Eur. J., 2010, 16, 12387; L. Kaufmann, E. V. Dzyuba, F. Malber, N. L. Löw, M. Groschke, B. Brusilowskij, J. Huuskonen, K. Rissanen, B. Kirchner, C. A. Schalley, Org. Biomol Chem. 2012, 10, 5954.

${ }^{18}$ Errors on the thermodynamic parameters may seem large; however, similar or even larger errors are generally acceptable for ITC experiments. See; Sessler, J. L.; Gross, D. E.; Cho, W.-S.; Lynch, V. M.; Schmidtchen, F. P.; Bates, G. W.; Light, M. E.; Gale, P. A. J. Am. Chem. Soc. 2006, 128, 12281.

${ }^{19}$ APEX2 v2013.10-0, (C) 2005-2013, Bruker AXS Inc., Madison, WI.

${ }^{20}$ COSMO v1.61, (C) 1999 - 2009, Bruker AXS Inc., Madison, WI.

${ }^{21}$ SAINT v8.34a, (C) 1997 - 2013, Bruker AXS Inc., Madison, WI.

${ }^{22}$ SADABS v2012/1, (C) 2012, Bruker AXS Inc., Madison, WI.

${ }^{23}$ SHELXTL v2013/4, (C 2013, Bruker AXS Inc., Madison, WI.

${ }^{24} \mathrm{CSD}$ code for one reported structure is QADYEA.

${ }^{25}$ P. Amrhein, P. L. Wash, A. Shivanyuk, J. Rebek, Org. Lett. 2002, 4,319 . 